\title{
Low Leukocyte Count
}

National Cancer Institute

\section{Source}

National Cancer Institute. Low Leukocyte Count. NCI Thesaurus. Code C162110.

A lower than average level of leukocytes in a sample. 